\title{
"MEU PAI ERA UM ARAMEU ERRANTE" (DEUTERONÔMIO 26,5)
}

"My Father was a Wandering Aramaean" (Deuteronomy 26:5)

Johan Konings*

Não vos esqueçais da hospitalidade, pois graças a ela alguns hospedaram anjos sem o perceber (Hebreus 13,2)

O presente fascículo da revista tematiza a hospitalidade concedida a estrangeiros e refugiados. "Hospitalidade para os estrangeiros? Para qualquer estrangeiro? Para o engenheiro vindo do Iraque graças às suas relações com alguma empresa brasileira ali? E também para o haitiano carente de qualificação profissional? E aquela moça que chegou aqui não se sabe com quem e ficou sozinha, grávida e perdida na rua?"

Tais são as perguntas que se ouvem. Uma coisa é hospitalidade para gente que de alguma maneira faz parte de nosso sistema, outra coisa a hospitalidade para quem é totalmente alheio. Ou para quem excede o orçamento.

O texto de Deuteronômio citado no título lembra que o ser migrante, estrangeiro, peregrino, como Jacó, o pai dos israelitas, está no DNA do "povo eleito". Mesmo considerando que os fiéis de Jesus Cristo constituem

* Faculdade Jesuíta de Filosofia e Teologia, Belo Horizonte, Minas Gerais, Brasil. 
agora o povo eleito (1Pd 2,1-10), a Primeira Carta de Pedro não deixa de os tratar como gente de outro povo e de outra casa, parepidemoi (1Pd 1,1; 2,11; cf. $\mathrm{Hb} 11,13$ ) e paroikoi (1Pd 2,11; cf. At 7,6.29; Ef 2,19) - e se até hoje somos chamados de "paroquianos", isso deveria alimentar a consciência de não estarmos em casa nesta sociedade, contrariamente ao que geralmente se entende por esse termo... Como os antigos "hebreus" - povo apátrida e sem organização -, assim também o povo eleito de Jesus Cristo é um povo peregrino, ádvena neste mundo. "O povo de Deus no deserto andava...".

Consciente de nosso estado peregrino, a Carta aos Hebreus, citada na epígrafe, exorta-nos a praticar a hospitalidade com a maior generosidade possível. Lembra a história de Abraão, da hospitalidade oferecida a Deus em pessoa, acompanhado de dois homens (Gn 18) que parecem ser anjos (Gn 19). Abraão não sabia que estava hospedando anjos, ou até Deus mesmo. Foi um gesto gratuito, embora recompensado quando, no final, Deus the promete um filho de Sara, sua legítima esposa (Gn 18,9-15). O caso tem alguma semelhança com o da mulher de Sunam, que hospedou o profeta Eliseu e recebeu em recompensa um filho, que, além disso, mais tarde ia ser ressuscitado de uma doença mortal pelo mesmo Eliseu (2Rs 2,8-37). História lembrada sutilmente por Jesus, quando aconselha a hospitalidade para com os profetas carismáticos das comunidades: a "recompensa de profeta" (Mt 10,41).

Muitos dos textos sobre a hospitalidade no Novo Testamento referem-se à hospitalidade para com membros das comunidades cristãs, missionários ambulantes etc.: At 16,15 (acolhida dos apóstolos por Lídia); Rm 12,13 (a hospitalidade entre os "santos"); Rm 16,23 (Gaio, o hospedeiro de Paulo e de toda a igreja); 1Tm 5,10 (hospitalidade e cuidado dispensados aos "santos"), 1Pd 4,9 (hospitalidade mútua). Em 3Jo encontramos uma ilustração típica de tais casos, negativa e positivamente (Gaio recebe e provê os missionários viajantes, Diótrefes os rechaça). Segundo Lc 10,6-7, os missionários não precisam recusar a hospitalidade que lhes for oferecida, pois "o operário merece seu salário". E muitos exegetas pensam que o hospedar forasteiros em Mt 25,45 talvez se refira aos membros de comunidades cristãs. $\mathrm{O}$ mesmo Lucas, porém, que nos Atos cita exemplos dessa hospitalidade entre os fiéis, anotou no seu Evangelho uma lição de Jesus sobre a extensão "criativa" de nossa benevolência e caridade: a história do samaritano. Portanto, não perguntemos, como o escriba: "Quem é nosso próximo?", pois, socraticamente, Jesus responde com outra pergunta: “De quem tu te tornas o próximo, a fim de cuidar dele?" (Lc 10,36).

Os forasteiros a serem acolhidos são afins ou são estranhos mesmo? O texto de Dt 5,14-15 estende o descanso sabático aos estrangeiros, os gerim, "porque tu foste escravo no Egito". Texto provocante, porque lembra que o paterfamilias poderia estar na situação do estrangeiro que está a seu serviço. 
Talvez devamos acentuar, na questão da hospitalidade, o "não saber". Abraão não sabia que estava hospedando a anjos e até a Deus mesmo. $\mathrm{O}$ justo de Mt 25,45 não sabia que havia praticado uma boa obra para com Filho do Homem e Juiz em pessoa. O samaritano de Lc 10,33 não foi movido por algum laço de afinidade com o homem que veio de Jerusalém, mas, somente, por compaixão. "Vai e faze o mesmo" (Lc 10,37).

Somos ádvenas, passageiros, viandantes. Não somos os donos da terra em que vivemos. Ela nos é confiada em gerência, não é nossa ( $\operatorname{Lv} 25,23)$. Cabe utilizá-la como deseja o verdadeiro adon, o Senhor. E do Senhor Altíssimo recebeu o mesmo Nome aquele que deu sua vida por nós (Fl 2,11). Então, o que fazer? "Quem tiver duas túnicas reparta com quem não tem, e quem tiver comida faça o mesmo" (Lc 3,11). Esse é o conselho do evangelho. A generosidade evangélica aplica-se também à hospitalidade. Na base da generosidade na hospitalidade está a gratidão por termos recebido de Deus tudo o que somos e temos. Contra os particularismos e partidarismo, Paulo ensina: "Tudo é vosso..., mas vós sois de Cristo, e Cristo é de Deus" (1Cor 3,22-23). “Que tens que não tenhas recebido?" (1Cor 4,7).

A sabedoria cristã nos ensina que não temos aqui cidade permanente $(\mathrm{Hb}$ $13,14)$. Por isso não devemos ter medo de repartir nossa morada com os que não têm. Depois da II Guerra Mundial os habitantes dos países bombardeados, dos dois lados do conflito, aprenderam literalmente a dividir suas casas com quem não tinha. A Primeira Carta de Pedro sugere que a comunidade cristã seja "um lar para quem não tem casa" (conforme o título do livro de J. H. Elliott nos anos 80).

O princípio evangélico é claro. Se se tiver condições, pratique-se. No sopro do Espírito, nosso discernimento deve nos ensinar o que fazer com as condições de que dispomos. Diante da realidade mundial dos migrantes e refugiados, não cabe um discernimento superficial, emocional. A situação é grave demais para ser tratada com leveza. É preciso um "ver" metódico, analítico, científico e bem informado, para ser exposto ao "julgar" segundo o evangelho de Cristo, a fim de que concebamos (e executemos) um "agir" realista e consistente. Tanto o "ver" como o "agir" supõem organização política, informação organizada, planejamento econômico, estratégia para a execução. Se, na Bíblia e ainda nos tempos da primeira colonização, havia terras em abundância, hoje tudo deve ser conduzido em função de um sólido planejamento, a médio e a longo prazo.

A questão dos refugiados e migrantes não é somente a questão de alguns indivíduos, de algumas famílias, por mais comoventes que sejam as fotografias que encontramos na mídia. É uma questão estrutural de nossa sociedade, de nosso modo de conceber o progresso. O que ficamos sabendo é somente a ponta de um iceberg de problemas. À questão da migração junta-se a questão demográfica e ecológica. Onde ficar com toda 
essa gente? O globo terrestre ainda comporta? Mesmo os terraplanistas se colocam essa pergunta! Nesta metade do ano corrente, a conta ecológica para 2019 já está entrando no vermelho. A natureza já não consegue repor em tempo o que tiramos dela... E há muito mais.

Não se trata somente de acolher os novos "hebreus". É preciso proporcionar-lhes condições de vida dignas e sustentáveis, para que não acabem morrendo ao chegar à praia. Para que não caiam nas redes dos traficantes de drogas e de humanos, da prostituição e do trabalho escravo. Para que sua fuga não se torne uma volta ao Egito, alvo das denúncias do Deuteronômio (Dt 17,16) e dos profetas (Is 31,1).

A própria generosidade hospitaleira, embora baseada no amor gratuito, não é coisa que se improvise. Exige uma política mundial e, portanto, vontade política. Não é por acaso que certas nações poderosas se recusam aos acordos mundiais, regridem para o particularismo, sob o impulso de líderes populistas que representam interesses escusos. "América para os americanos" ensinava a doutrina de Monroe, mas a história ensinou que a América não era suficiente para eles.

Quando tudo é submetido ao crivo do proveito próprio nunca se chega à equidade do bem para todos. Presenciamos uma farra de egoísmo e superficialidade. Cegueira coletiva diante das migrações, que não são acidentes esporádicos de alguma região, mas sintomas de todo o globo adoentado. Migrações não apenas internas como o Brasil sempre conheceu, mas agora também externas, não provindas da Europa em crise como no fim do século XIX e no início do século XX, mas dos países vizinhos e das populações que poderíamos chamar de protocoloniais.

As razões dos fluxos crescentes de refugiados são, por um lado, os desequilíbrios econômicos, a diminuída demanda de mão de obra, as pressões políticas, e, por outro lado, o esgotamento da terra pela exploração irresponsável e predadora e pelas primeiras consequências drásticas, quiçá irreversíveis, da mudança climática, causando morte da biodiversidade e visível desertificação. Acrescentam-se o problema dos governos autoritários que provocam a emigração e a falta de interesse político em criar condições para essas pessoas permanecerem em suas terras. Ouvem-se sempre as mesmas desculpas, falta de água, faltam recursos... mas falta mesmo é de políticas públicas. Queremos ocupar mais terras, expulsando ou matando as populações enraizadas, rompendo o equilíbrio natural e aumentando o aquecimento global, pondo em risco a sustentabilidade do nosso ambiente vital. As advertências do Papa Francisco não são invenções da imaginação. Infelizmente, mesmo na própria Igreja católica nem sempre são ouvidas.

Entretanto não devemos desconhecer as muitas iniciativas, quer individuais, quer coletivas que surgiram nesses últimos anos como respostas à neces- 
sidade imediata, pois não podemos deixar morrer o refugiado enquanto discutimos a solução a longo prazo. A própria Companhia de Jesus no Brasil, e inclusive a Faculdade Jesuíta em Belo Horizonte participaram de uma campanha de acolhida, colocação e emprego para refugiados de diversas regiões.

Concluindo. O princípio bíblico e evangélico da hospitalidade como forma específica da caridade gratuita é inegociável. Nosso discernimento cristão, que é provocado pelo desejo de agir efetiva e eficazmente e guiado pelo Espírito de Cristo, urge conscientização a respeito do tamanho e da complexidade do problema e criatividade na busca de respostas. A observação analítica e crítica da realidade se revela assustadora e torna visíveis os problemas estruturais. Entretanto, não podemos regatear a obrigação evangélica da hospitalidade gratuita, proativa e livre de egoísmo. Isso nos levará a ações emergenciais indispensáveis, mas exige também uma ação política ampla a médio e a longo prazo, para a qual devemos pressionar os governos (o que implica escolher governos adequados...).

Editorial submetido em 15.06.2019 e aprovado em 07.08.2019.

Johan Konings SJ é doutor em Teologia Bíblica pela Katholieke Universiteit Leuven (1977), professor de Teologia Bíblica, atuando nos programas de Graduçao e de Pós-graduação em Teologia na Faculdade Jesuíta de Filosofia e Teologia (FAJE), Belo Horizonte. Orcid.org/00000001-7200-0753. E-mail: konings@faculdadejesuita.edu.br

Endereço: Av. Dr. Cristiano Guimarães, 2127 - Planalto

31720-300 Belo Horizonte - MG 